\title{
Some Trends in Development of Measuring Instruments and Systems
}

\author{
Stanislav Fabian, Martin Lorko
}

\begin{abstract}
The paper presents some important trends in the development of measuring instruments and systems (MIS), which have come about as a result of general civilization progress and specific trends in the development of production technologies. The set presented consists of 29 important developed trends.
\end{abstract}

\section{Introduction}

The quality of products and production is one of the important factors which determine and condition speeding up the development of civilization towards a new, more demanding scale of values in correspondence with the principles of permanently sustainable development. Quality also influences economic effectiveness, the ability to compete and also the survival of companies in a market environment. To reach the required steady and stable high quality, it is necessary to manage the process of quality creation. The basic precondition for successful and effective quality management is the effective assessment of obtained quality levels by measuring the parameters of those features which influence the satisfaction of customers' needs and therefore the quality of products. The design and securing of progressive and effective processes of measuring requires, among others, knowledge of trends in development of measuring instruments and systems. This paper wishes to make a contribution to this field..

\section{Initial attributes}

The presented set of trends is based initially on the formulation of these starting point attributes:

- trends in general civilization development

- expected prosperity or depression of the world economy

- level of the market system, (importance of competition environment, solvency of customers)

- development in the field of production technologies

- development in the field of systems of quality management (and their integration with other systems of manufacturing technology control)

\section{Some important trends in the development of measuring instruments and systems}

The following trends are among the important developments MIS expressed in a brief and concentrated form:
- globalization in the process of development and production of measuring instruments and systems

- wider implementation of knowledge from space and military research in design, production, operation and servicing of measuring instruments and systems

- development of new measuring instruments and systems of new generation on the base of new technical principles, new materials and technologies

- transfer from the predominance of individual measuring instruments to measuring systems and technologies

- increasing the degree of automation of measuring, mainly automation of insertion, positioning, fixation, releasing and selection of measured parts or their positioning following further operations of technological progress by implementing automation technology, e.g. single-purpose manipulators and robots with high speed and accuracy of movement, high number of degrees of idling and therefore increased possibilities of movement, for example the ability to get into hollows of complicated shapes of measured parts

- increasing the proportion of costs of measuring systems and control technologies in total costs of production technologies, mainly in the area of "high technology"

- wider implementation of "fuzzy theory" in increasing the level of management of measuring instruments and systems

- using knowledge of technology of molecular electronics, mainly in automation of measuring and evaluation of results of measurement

- implementation of nanotechnology in production of very precise parts with small dimensions for measuring instruments

- using biotechnology in development of new measuring principles

- higher implementation of the theory of partial geometry and chaos theory in the development of new measuring methods and means for the measurement of very irregular shapes, for example surfaces with small dimensions

- wider implementation of progressive technologies, for example Rapid Prototyping, through which the course of development of measuring systems is considerably shortened

- complete supply of measuring systems together with air-conditioning or other equipment which enable the operation of measuring instruments and systems also in more difficult operating conditions

- increasing the range of usage of measuring instruments and systems in the process of monitoring of production systems serving as a basise for their regulation and management 
- increasing the range of usage of measuring instruments and systems in the development of automated securing of quality production in production systems. For example, automated measurement of numeral value of the key parameters of an instrument, its evaluation and correction according to regulation limits or etalon values or according to the function of predescribed values of measured parameters in time

- increasing range of usage of measuring systems with dismantling-free diagnosis of production systems

- decreasing time of monitoring (or time of stabilization of measured quantity)

- increasing requirements for measurement precision

- increasing completeness and effectiveness of the service of measuring instruments and systems, for example, by using advisory and decision-making activities of leading experts in the area of metrology through internet, e-mail, using expert systems

- development of special control technology including measuring instruments and systems for the needs of measuring in nanotechnology

- intensification of the development of measuring instruments and systems for measuring physical values in extreme working conditions

- increasing comfort of service, for example through more effective training systems, retraining of service of measuring systems by using video, simulation programs, principles of virtual reality, but also through the creation of simpler, more apt, understandable, precise but shorter instructions for usage and maintenance

- more intense and effective process of freezing - prevention of mistakes in measuring concurrence through, for example, the elimination of wrong activity of service of measuring systems through the automation of reading and evaluation of measured data, using measuring instruments and systems with automatic positioning and fixing measured parts

- increasing reliability of measuring systems mainly by using dynamic systems of preventive exchange of functionally important elements, using more quality materials, parts with high and guaranteed level of reliability, using the principle of heredity of construction of measuring systems

- using materials of new generation produced for example in the environment without gravitation (with decreased gravitation) when even structure with following improvement of their mechanic features can be reached, or in an absolute vacuum or absolutely dry conditions or simultaneous influence of various factors and combinations. These are mainly materials that are more resistant to wear, have higher invariability of features, for example stable dimensions, inert with regard to changes of parameters of working conditions (temperature, humidity, pressure, vibrations, etc.), Intelligent Materials (Smart), e.g. Shape Memory Alloys (SMA)

- implementation of methods of simulation and optimation when creating control documentation and design of measuring systems, but also when analysing the consequences of the attained degree of measurement precision
- global implementation of principles of qualimetry (with methods for quantification of quality, qualimetric comparisons and analyses) when setting technical tasks for the research, development and innovation of measuring instruments and systems and as a qualified basis for their evaluation and certification

- considerably shortening the time of measurement (total time of control operations) of the product:

a. through wider implementation of measuring chains in complete control technologies decreasing mainly helping times for transport and manipulation of measured parts and eliminating time for positioning and fixing measured parts

b. by using new principles enabling to increase the speed of measuring with the same level of measurement precision

c. by increasing the numbers of measured pieces during one measurement, positioning and fixing

- implementation of knowledge engineering during development of control, measuring and testing systems

\section{Conclusion}

The paper presents a set of some important trends in the development of measuring instruments and systems based on initial attributes which influence the presented development trends in a decisive way. The paper does not consider all trends of development of measuring instruments and systems but gives more valuable knowledge, non-traditional views and new information from the field. Presented trends of development are worked out on basis of the authors' own knowledge and research into the views of significant experts from the field of quality control development. Some of them are introduced in the reference list.

\section{References}

[1] Bateštová, E./Marcinin, J. N.: Opening look into Vision the Next Generation Bionic manufacturing Systems. Transactions of Universities of Košice, Vol. 9, No. 2, TU Košice 1999, 26-29.

[2] Bokuava, G./Nasilko, K.: Úlohy výrobných technológií na prahu tretieho tisícroia. In: Nové smery vo výrobných technológiách V. TU Košice, FVT Prešov 2000, 23-28.

[3] Buda, J.: Od industrializácie ku globalizácii. In: Nové smery vo výrobných technológiách V. TU Košice, FVT Prešov 2000, 29-32.

[4] Fabian, S.: Trends of Manufacturing Process Relability. In: Ingineria si managementu sistemelor de productie. Volumul 5. Targu Mures, Romania, 2000, 47-49. IDBN 973-8084-17-2.

[5] Fabian, S.: Set of Methods for Qualitative Analysis and Comparison as Applied to ir. Zborník vedeckých prác, TU SjF Košice, 2002, 103-108, ISBN 80-7099-826-1

[6] Fabian, S.: Kniektorým trendom vývoja výrobných technológií. Výrobné inžinierstvo 2-3/2002, Prešov 2002, 37-42, ISSN 1335-7972-XX. 
[7] Fronc, M.: Iniciatíva COST zameraná na nanovedy. Informaný materiál MŠ Bratislava, spracovaný z podkladov skupiny Nanoscience and Technology Advisory Group (NanoSTAG), ktorá tvorí poradný orgán Európskej komisie pre nanovedy. Bratislava 2000.

[8] Gebhardt, A.: Rapid Prototyping. Carl Hanser Verlag, München, 1996.

[9] Havrila, M.: Actual trend in automation machine tool. In: Akademická Dubnica 98, Dubnica nad Váhom, 1998, 211215.

[10] Kalini, B.: Megatrendy v automatizácii výroby. AMS 1/97, TU SjF Košice, 1997.

[11] Košturiak, J./Gregor, M.: Die Simulation von Produktionssystemen. Springer Verlag, Wien, 1995.

[12] Lorko, M.: Manažment, TU Košice, FVT Prešov, 2000, ISBN 80-7099-676-5.

[13] Marcinin, J. N./Kárník, L.: Aplikácia technológií virtuálnej reality v technickej praxi. In: COMTEP 98, KR SjF TU Košice 1998, 121-124.

[14] Naisbitt, J.: Megatrendy 2000. Bradlo, Bratislava 1998.

[15] Palák, F.: Možnosti využitia technológie simulácií virtuálnych prototypov pre potreby strojárskeho priemyslu. Strojárstvo 5/1999, 55-59.

\section{Authors}

Prof. Dr.-Ing. Stanislav Fabian

Technical University in Košice

Faculty of Manufacturing Technologies

Bayerova 1, 08001 Prešov, Slovakia

Tel. +421517723504

E-Mail: fabian.stanislav@fvt.sk

Prof. Dr.-Ing. Martin Lorko

Technical University in Košice

Faculty of Manufacturing Technologies

Bayerova 1, 08001 Prešov, Slovakia

Tel. +421517723012

E-Mail: lorko.martin@fvt.sk 